\title{
Common polymorphisms of the PPAR- $\gamma 2$ (Pro12Ala) and PGC-1 $\alpha$ (Gly482Ser) genes are associated with the conversion from impaired glucose tolerance to type 2 diabetes in the STOP-NIDDM trial
}

\author{
L. Andrulionytè ${ }^{\cdot}$ J. Zacharova ${ }^{1} \cdot$ J.-L. Chiasson ${ }^{2} \cdot$ M. Laakso ${ }^{1}$ for the STOP-NIDDM Study Group \\ ${ }^{1}$ Department of Medicine, University of Kuopio, Kuopio, Finland \\ ${ }^{2}$ Research Centre, Centre Hospitalier de l'Université de Montréal, Hôtel-Dieu, Department of Medicine, University of Montreal, \\ Quebec, Canada
}

\section{Abstract}

Aim/hypothesis. We investigated the effects of the common polymorphisms in the peroxisome proliferator-activated receptor $\gamma 2(P P A R-\gamma 2$; Pro12Ala) and in PPAR- $\gamma$ coactivator $1 \alpha(P G C-1 \alpha$; Gly482Ser) genes on the conversion from impaired glucose tolerance to type 2 diabetes in participants in the STOP-NIDDM trial. This trial aimed to study the effect of acarbose in the prevention of type 2 diabetes.

Methods. Genotyping was performed in 770 study subjects whose DNA was available. The Gly482Ser variant in the $P G C-1 \alpha$ gene was determined with the polymerase chain reaction amplification, Hpa II enzyme digestion, and gel electrophoresis. The Pro12Ala polymorphism of the PPAR- $\gamma 2$ gene was determined by the polymerase chain reaction-singlestrand conformation polymorphism analysis.

Results. The Pro12Pro genotype of the PPAR- $\gamma 2$ gene predicted the conversion to diabetes in women in the acarbose group (odds ratio $2.89,95 \%$ CI 1.20 to 6.96 ; $p=0.018$ ). The $482 \mathrm{Ser}$ allele of the $P G C-1 \alpha$ gene had a significant interaction with the mode of treatment ( $p=0.012)$, and in the placebo group the $482 \mathrm{Ser}$ allele was associated with a 1.6-fold higher risk for type 2 diabetes compared to the Gly482Gly genotype (95\% CI 1.06 to $2.33 ; p=0.023)$. Acarbose prevented the development of diabetes independently of the genotype of the PPAR- $\gamma 2$ gene, but only the carriers of the $482 \mathrm{Ser}$ allele of the $P G C-1 \alpha$ gene were responsive to acarbose treatment.

Conclusion/interpretation. We conclude that the Pro12Pro genotype of the PPAR- $\gamma 2$ gene and the $482 \mathrm{Ser}$ allele of the $P G C-1 \alpha$ gene are associated with the conversion from impaired glucose tolerance to type 2 diabetes in the STOP-NIDDM trial.

Keywords Impaired glucose tolerance - PGC-1 alpha • Polymorphism · PPAR gamma - Type 2 diabetes.
Received: 13 January 2004 / Accepted: 5 August 2004

Published online: 8 December 2004

(C) Springer-Verlag 2004

M. Laakso ( )

Department of Medicine, University of Kuopio,

70210 Kuopio, Finland

E-mail: markku.laakso@kuh.fi

Tel.: +358-17-172151, Fax: +358-17-173993

Abbreviations: FPG, fasting plasma glucose $\cdot$ HOMA-IR, homeostasis model assessment for insulin resistance - PGC-1, peroxisome proliferator-activated receptor $\gamma$ coactivator- 1 . PPAR, peroxisome proliferator-activated receptor $\cdot$ SSCP, single-strand conformation polymorphism $\cdot$ STOP-NIDDM, Study To Prevent Non Insulin Dependent Diabetes Mellitus

The members of the STOP-NIDDM Study Group are listed in a previous article published in the Lancet (2002; 359:2072-2077)

\section{Introduction}

Type 2 diabetes is a common disease due to both genetic and environmental factors [1, 2, 3, 4]. Although up to 40 genes have been reported to be associated with this disease, the Pro12Ala polymorphism of the peroxisome proliferator-activated receptor $\gamma 2$ $(P P A R-\gamma 2)$ gene has been identified as the most widely reproduced genetic variation for the risk of type 2 diabetes [4]. Another important association with type 2 diabetes has been reported for a missense variant (Gly482Ser) in the peroxisome proliferator-activated receptor $\gamma$ coactivator-1 $(P G C-1 \alpha)$ gene [4].

$P P A R \gamma$ is a ligand-activated transcription factor, a member of the nuclear hormone receptor superfamily, 
that functions as a heterodimer with a retinoid $\mathrm{X}$ receptor (RXR) to promote transcription of numerous target genes [5, 6]. PPAR- $\gamma 2$, an isoform of PPAR- $\gamma$ with 28 additional amino acids at its $\mathrm{N}$-terminus, is expressed almost exclusively in adipose tissue [7]. It plays a key role in adipogenesis $[8,9,10,11]$, is involved in the regulation of insulin sensitivity $[12,13]$, and is the major functional receptor for the thiazolidinedione class of insulin-sensitising drugs [11, 14]. Therefore, the PPAR- $\gamma$ gene has been viewed as a "thrifty gene", with an important role in the development of type 2 diabetes and diabetes-related traits [7, 15]. Additionally, the Prol2Ala substitution in exon B of the PPAR- $\gamma 2$ gene, first reported in Caucasians [16], has been associated with diabetes mellitus $[17,18,19$, $20,21,22,23,24,25,26,27,28]$. Although not all associations have been consistent, a meta-analysis of published studies has confirmed a modest (1.25-fold), but statistically significant, increase in diabetes risk for the Prol2Pro genotype [4, 19].

$P G C-1$ co-activates a series of nuclear receptors including PPAR- $\gamma$, and controls transcription of genes involved in adaptive thermogenesis, adipogenesis and oxidative metabolism $[29,30,31]$. Moreover, $P G C$ $1 \alpha$ regulates the determination of muscle fibre type [32], enhances glucose uptake by controlling insulinsensitive glucose transporter (GLUT-4) expression in muscle cells [33] and is implicated in hepatic gluconeogenesis by increasing gene transcription of phosphoenolpyruvate carboxykinase and glucose-6-phosphatase [34]. Genes involved in oxidative metabolism and responsive to $P G C-1 \alpha$, as well as $P G C-1 \alpha$ itself, have been showed to be co-ordinately down-regulated in diabetic subjects $[35,36]$ and even in insulin-resistant individuals [37]. The Gly482Ser variant in the $P G C$ - $1 \alpha$ gene has been reported to be associated with type 2 diabetes in Danish [38] and Japanese [39] subjects. In contrast, no association was found in French Caucasians [40] or in Pima Indians [41] and in additon, no interaction was observed between this variant and the Pro12Ala polymorphism of the PPAR- $\gamma 2$ gene [38].

We investigated the association of the Prol2Ala polymorphism of the $P P A R-\gamma 2$ gene, and the Gly482Ser variant of the $P G C-1 \alpha$ gene with the risk of type 2 diabetes among the participants in the Study To Prevent Non Insulin Dependent Diabetes Mellitus (STOP-NIDDM).

\section{Materials and methods}

Study population and design. The STOP-NIDDM trial design and rationale have previously been described in detail [42]. The aim of this study was to investigate the effect of $\alpha$-glucosidase inhibitor acarbose on the prevention of type 2 diabetes in a population with IGT. This international, multicentre, double-blind, placebo-controlled trial, conducted in Canada, Germany, Austria, Finland, Sweden, Norway, Denmark, Israel and
Spain randomised 1429 subjects with fasting plasma glucose 5.6-7.7 $\mathrm{mmol} / \mathrm{l}$ and 2-h plasma glucose $7.8-11.0 \mathrm{mmol} / \mathrm{l}$ to either the acarbose or placebo group.

All patients met with a dietician before randomisation and then on a yearly basis, and were recommended to follow a weight-reduction or weight-maintenance diet and encouraged to exercise regularly. Fasting plasma glucose (FPG) was measured every 3 months and a 2 -h glucose tolerance test was performed if FPG levels were $\geq 7 \mathrm{mmol} / \mathrm{l}$. All subjects underwent annual OGTT to evaluate the conversion to diabetes according to the World Health Organization criteria [43]. Improvement of glucose tolerance (i.e. return to normal glucose tolerance (NGT), either from IGT or from diabetes) was also assessed. Mean follow-up time for the whole population was $3.3 \pm 1.2$ years.

DNA was available from 770 subjects ( 387 men and 383 women), 356 of whom were initially allocated to acarbose and 414 to placebo. Their mean body mass index (BMI) was $30.8 \pm 4.1 \mathrm{~kg} / \mathrm{m}^{2}$ and their mean age was $54.7 \pm 7.9$ years. DNA was not available for subjects recruited in Israel and Sweden. Subjects who were included in the study did not differ from those whose DNA was not available with respect to sex and age, baseline characteristics such as weight, BMI, waist circumference and waist-to-hip ratio and laboratory measures such as fasting and 2-h glucose and insulin. However, those subjects whose DNA was available, had a higher systolic blood pressure and a significantly higher incidence of diabetes ( 40.3 vs $32.8 \%, p=0.004$ ) compared to those whose DNA was not available. The incidence of diabetes was higher among subjects whose DNA was available compared to subjects whose DNA was not available for all countries with the exception of Denmark and Germany. All participants signed an informed consent form, approved by appropriate Institutional Review Boards.

Measurements. Anthropometric measurements, nutritional evaluations and laboratory analyses were carried out at baseline, at annual visits and at the end of the study, as previously reported [42, 44]. Homeostasis model assessment for insulin resistance (HOMA-IR) was calculated according to the formula: fasting plasma glucose $(\mathrm{mmol} / \mathrm{l}) \times$ fasting serum insulin $(\mathrm{mU} / \mathrm{l}) / 22.5$ [45].

Genomic DNA was isolated from human leukocytes by the salt-precipitation method. Genotyping of the Gly482Ser polymorphism of the $P G C-1 \alpha$ gene was performed with the polymerase chain reaction-restriction fragment length polymorphism (PCR-RFLP) method. The sequences of the primers were 5'-TGC TAC CTG AGA GAG ACT TTG-3' (forward primer) and 5'-CTT TCA TCT TCG CTG TCA TC-3' (reverse primer). PCR amplification was carried out in a volume of $10 \mu \mathrm{l}$, that contained $50 \mathrm{ng}$ of genomic DNA, 5 pmol of each primer, $10 \mathrm{mmol} / \mathrm{l}$ Tris- $\mathrm{HCl}(\mathrm{pH} 8.8), 50 \mathrm{mmol} / \mathrm{l} \mathrm{KCl}$, $1.5 \mathrm{mmol} / \mathrm{l}$ of $\mathrm{MgCl}_{2}, 0.1 \%$ Triton X-100, $112 \mu \mathrm{mol} / \mathrm{l} \mathrm{dNTP}$ and $0.25 \mathrm{U}$ of DNA polymerase (Dynazyme DNA polymerase, Finnzymes, Espoo, Finland). Reaction mixtures were incubated at $94^{\circ} \mathrm{C}$ for $4 \mathrm{~min}$, followed by 35 cycles of denaturation at $94^{\circ} \mathrm{C}$ for $30 \mathrm{~s}$, annealing at $56^{\circ} \mathrm{C}$ for $30 \mathrm{~s}$ and extension at $72^{\circ} \mathrm{C}$ for $30 \mathrm{~s}$, with the final extension at $72^{\circ}$ for $6 \mathrm{~min}$, and 260-bp length PCR products were then digested with Hpa II at $37^{\circ} \mathrm{C}$ overnight, resolved by electrophoresis on $9 \%$ polyacrylamide gel, and visualised by staining with ethidium bromide.

The Pro12Ala polymorphism of the PPAR- $\gamma 2$ gene was detected by polymerase chain reaction-single-strand conformation polymorphism (PCR-SSCP) analysis as previously described [17]. The 167-bp length product, encompassing the polymorphic site was amplified by PCR with the sense primer 5'-GAC AAA ATA TCA GTG TGA ATT ACA GC-3' and the 
Table 1. Clinical and biochemical characteristics of the subjects in the STOP-NIDDM study in relation to the Prol2Ala polymorphism of the $P P A R-\gamma 2$ gene and the Gly482Ser polymorphism of the $P G C$ - $1 \alpha$ gene

\begin{tabular}{|c|c|c|c|c|}
\hline & \multicolumn{2}{|c|}{$P P A R-\gamma 2$ genotypes } & \multicolumn{2}{|c|}{$P G C$ - $1 \alpha$ genotypes } \\
\hline & 12Ala & Pro12Pro & Gly482Gly & $482 \mathrm{Ser}$ \\
\hline$n$ & 178 & 592 & 334 & 436 \\
\hline Sex (men/women) & $88 / 90$ & $299 / 293$ & $168 / 166$ & $219 / 217$ \\
\hline Age (years) & $54.9 \pm 7.8$ & $54.7 \pm 7.9$ & $54.6 \pm 7.9$ & $54.9 \pm 7.9$ \\
\hline Diastolic blood pressure (mmHg) & $82.5 \pm 9.9$ & $82.9 \pm 9.1$ & $82.8 \pm 9.2$ & $82.8 \pm 9.4$ \\
\hline Body mass index $\left(\mathrm{kg} / \mathrm{m}^{2}\right)$ & $31.11 \pm 4.45$ & $30.65 \pm 4.00$ & $30.79 \pm 3.98$ & $30.74 \pm 4.21$ \\
\hline Waist-to-hip ratio & $0.93 \pm 0.08$ & $0.92 \pm 0.08$ & $0.93 \pm 0.08$ & $0.92 \pm 0.08$ \\
\hline Fasting plasma glucose (mmol/l) & $6.23 \pm 0.57$ & $6.27 \pm 0.53$ & $6.25 \pm 0.52$ & $6.27 \pm 0.54$ \\
\hline 2 -h plasma glucose $(\mathrm{mmol} / \mathrm{l})$ & $9.25 \pm 1.10$ & $9.26 \pm 1.04$ & $9.28 \pm 1.10$ & $9.24 \pm 1.01$ \\
\hline Fasting insulin $(\mathrm{pmol} / \mathrm{l})$ & $97.4 \pm 55.6$ & $97.9 \pm 53.2$ & $95.9 \pm 47.1$ & $99.2 \pm 58.3$ \\
\hline HDL cholesterol (mmol/l) & $1.23 \pm 0.34$ & $1.18 \pm 0.32$ & $1.19 \pm 0.31$ & $1.20 \pm 0.33$ \\
\hline LDL cholesterol $(\mathrm{mmol} / \mathrm{l})$ & $3.61 \pm 0.96$ & $3.61 \pm 0.88$ & $3.64 \pm 0.94$ & $3.58 \pm 0.87$ \\
\hline Total triglycerides $(\mathrm{mmol} / \mathrm{l})$ & $2.01 \pm 1.23$ & $2.00 \pm 1.07$ & $2.07 \pm 1.09$ & $1.95 \pm 1.12$ \\
\hline \multicolumn{5}{|l|}{ Follow-up values ${ }^{a}$} \\
\hline Change in weight $(\mathrm{kg})$ & $-0.31 \pm 4.56$ & $0.06 \pm 4.59$ & $0.02 \pm 4.59$ & $-0.05 \pm 4.58$ \\
\hline Change in waist circumference $(\mathrm{cm})$ & $-0.03 \pm 6.16$ & $-0.21 \pm 5.87$ & $-0.01 \pm 5.87$ & $-0.29 \pm 5.99$ \\
\hline Change in fasting plasma glucose $(\mathrm{mmol} / \mathrm{l})$ & $-0.07 \pm 0.74$ & $-0.06 \pm 0.85$ & $-0.04 \pm 0.79$ & $-0.07 \pm 0.86$ \\
\hline Change in 2 -h plasma glucose $(\mathrm{mmol} / \mathrm{l})$ & $-0.35 \pm 2.67$ & $0.12 \pm 2.70$ & $-0.03 \pm 2.57$ & $0.05 \pm 2.79$ \\
\hline Change in fasting insulin $(\mathrm{pmol} / \mathrm{l})$ & $-1.8 \pm 72.2$ & $-0.7 \pm 52.5$ & $2.7 \pm 50.6$ & $-3.9 \pm 62.5$ \\
\hline Change in $2-\mathrm{h}$ insulin $(\mathrm{pmol} / \mathrm{l})$ & $-102.8 \pm 360.6$ & $-15.1 \pm 405.6^{b}$ & $-17.0 \pm 357.8$ & $-49.1 \pm 425.2$ \\
\hline
\end{tabular}

Data are $n$ or means $\pm \mathrm{SD}$; a the non-parametric Mann-Whitney test was used to compare these variables; ${ }^{\mathrm{b}} p$ value $<0.05$, while comparing the two genotype groups

antisense primer $5^{\prime}$-CCC AAT AGC CGT ATC TGG AAG G-3'. Amplification was performed using $50 \mathrm{ng}$ of DNA in a total volume of $6 \mu$ l containing $2.8 \mathrm{pmol}$ of each primer, $10 \mathrm{mmol} / \mathrm{l}$ Tris- $\mathrm{HCl}$ (pH 8.8), $50 \mathrm{mmol} / \mathrm{l} \mathrm{KCl}, 1.5 \mathrm{mmol} / \mathrm{l}$ of $\mathrm{MgCl}_{2}, 0.1 \%$ Triton X-100, $95 \mu \mathrm{mol} / 1 \mathrm{dNTP}, 0.14 \mathrm{U}$ DNA polymerase (Dynazyme DNA polymerase, Finnzymes, Espoo, Finland), and $0.25 \mu \mathrm{Ci}\left[\alpha_{-}{ }^{33}\right] \mathrm{dCTP}$. The cycling programme was denaturation step at $94^{\circ} \mathrm{C}$ for $4 \mathrm{~min}$, followed by 35 cycles of denaturation at $94^{\circ} \mathrm{C}$ for $30 \mathrm{~s}$, annealing and extension at $66^{\circ} \mathrm{C}$ for $1 \mathrm{~min}$, with the final extension at $72^{\circ} \mathrm{C}$ for $6 \mathrm{~min}$. Thereafter, PCR products were diluted 4-fold with $0.1 \%$ SDS and $10 \mathrm{mmol} / \mathrm{l}$ EDTA and the loading mix $(95 \%$ formamide, $20 \mathrm{mmol} / \mathrm{l}$ EDTA, $0.05 \%$ bromphenol blue, $0.05 \%$ xylene cyanol) was then added (1:1). After denaturation at $94^{\circ} \mathrm{C}$ for $4 \mathrm{~min}$, the samples were placed on ice and $4 \mu \mathrm{l}$ of each was loaded onto non-denaturating 6\% acrylamide gels. Electrophoresis was carried out at $38^{\circ} \mathrm{C}$ for approximately $5 \mathrm{~h}$, the gels were subsequently dried and autoradiographed overnight.

Statistical analysis. All statistical analyses were undertaken using the Statistical Package for Social Sciences (SPSS, Chicago, Ill., USA) version 11.0 for Windows. Data are expressed as either mean \pm SD or percentages, unless indicated otherwise. The normality of the distribution of variables was tested with the Kolmogorov-Smirnov test, and parameters that did not have a normal distribution were logarithmically transformed (systolic and diastolic blood pressure, weight, BMI, fasting and 2-h plasma glucose and insulin). Comparison of variables between the genotype groups was carried out with the two- tailed Student's $t$ test or the Mann-Whitney non-parametric test, when appropriate. Categorical variables were compared using the chi square test. In order to evaluate whether the $P G C-1 \alpha$ and PPAR- $\gamma 2$ polymorphisms and other variables predicted the development of type 2 diabetes, odds ratios and $95 \%$ CIs (non-adjusted and adjusted for confounding variables) were calculated by logistic regression analysis. A $p$-value equal to or less than 0.05 was considered to be statistically significant.

\section{Results}

In 770 study subjects the frequencies of genotypes were as follows: 592 (76.9\%) Pro12Pro, 164 (21.3\%) Pro12Ala and 14 (1.8\%) Ala12Ala for the PPAR- $\gamma 2$ gene and 334 (43.4\%) Gly482Gly, 339 (44.0\%) Gly482Ser and 97 (12.6\%) Ser482Ser for the PGC-1 $\alpha$ gene. The frequencies of the $12 \mathrm{Ala}$ allele ranged from 0.186 to 0.307 and of the $482 \mathrm{Ser}$ allele from 0.498 to 0.780 in different countries (Austria was excluded because of a low number of cases). No differences in the frequencies of these polymorphisms were found between the acarbose and placebo groups and all genotypic distributions were in Hardy-Weinberg equilibrium. 


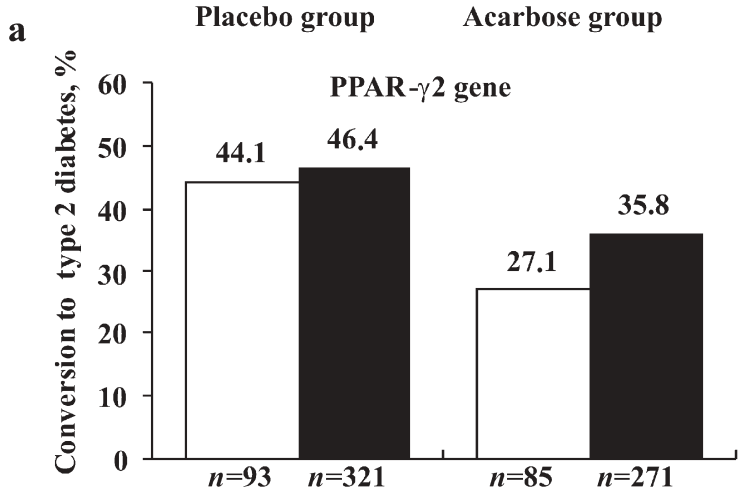

b

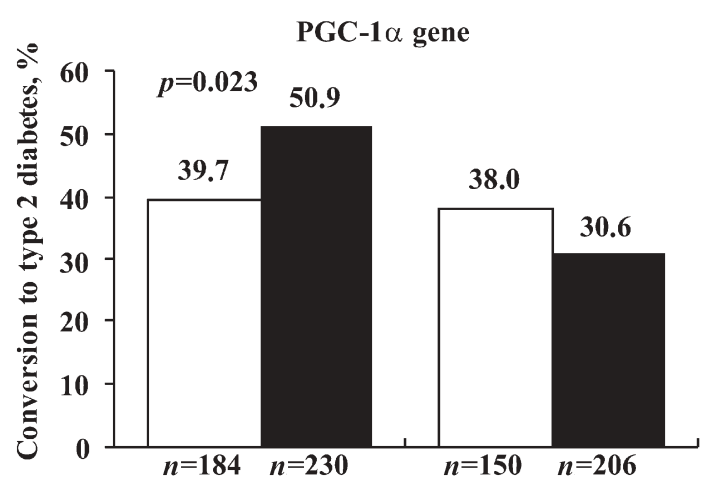

Fig. 1. Conversion (\%) to type 2 diabetes in the placebo group and in the acarbose group in relation to the presence of the 12 Ala allele (white bars) and the Pro12Pro genotype (black bars) of the PPAR- $\gamma 2$ gene (a). Conversion (\%) to type 2 diabetes in the placebo group and in the acarbose group in relation to the presence of the Gly482Gly genotype (white bars) and the $482 \mathrm{Ser}$ allele (black bars) of the $P G C$ - $1 \alpha$ gene (b)

Clinical characteristics, fasting and 2-h plasma glucose, fasting and 2-h serum insulin, HOMA IR and lipid levels at baseline did not differ significantly in relation to the Pro12Ala polymorphism of the PPAR$\gamma 2$ gene or the Gly482Ser polymorphism of the $P G C$ $1 \alpha$ gene either in the entire study population (Table 1 ) or within the acarbose and placebo groups (data not shown). Carriers of the 12Ala allele showed a significantly higher reduction in 2 -h serum insulin levels $(p=0.035)$ compared to subjects with the Prol2Pro genotype. In the placebo group, carriers of the $482 \mathrm{Ser}$ allele, compared to carriers of the Gly482Gly genotype, showed a significant increase in their 2-h glucose levels during the 3 -year follow-up $(0.66 \pm 2.81$ vs $0.15 \pm 2.56 \mathrm{mmol} / \mathrm{l}, p=0.048$ ) whereas carriers of the $482 \mathrm{Ser}$ allele in the acarbose group showed a more pronounced decrease in their 2-h glucose levels compared to the 2-h glucose levels among carriers of the Gly482Gly genotype $(-0.64 \pm 2.60$ vs $-0.25 \pm 2.58$ $\mathrm{mmol} / \mathrm{l}, p=0.131$ ).

During the follow-up of 3.3 years, a total of 310 genotyped subjects (190 in the placebo group and 120 in the acarbose group) developed type 2 diabetes. In the placebo group four of eight subjects $(50.0 \%)$ having the Ala 12Ala genotype, 37 of 85 subjects (43.5\%)
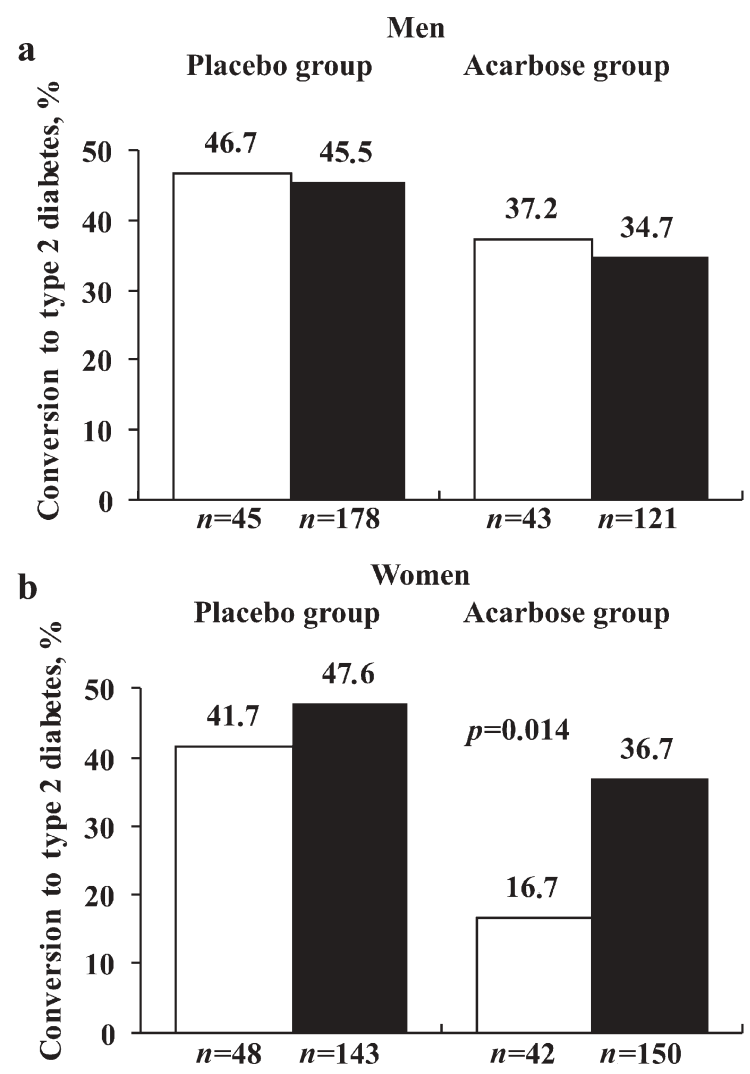

Fig. 2. Conversion (\%) to type 2 diabetes in the placebo group and in the acarbose group in men (a), and conversion (\%) to type 2 diabetes in the placebo group and in the acarbose group in women (b) according to the presence of the 12Ala allele (white bars) and the Prol2Pro genotype (black bars) of the $P P A R-\gamma 2$ gene

having the Pro12Ala genotype and 149 of 321 subjects (46.4\%) having the Prol2Pro genotype of the PPAR- $\gamma 2$ gene developed diabetes. In the acarbose group the corresponding numbers were one of six (16.7\%), 22 of $79(27.8 \%)$ and 97 of $271(35.8 \%)$. In both treatment groups there was a trend for subjects with the Prol2Pro genotype to have a higher incidence of type 2 diabetes, but the difference was not statistically significant $(p=0.673$ in the placebo group and $p=0.131$ in the acarbose group; Fig. 1a). When the results were analysed by sex, the Pro12Pro genotype was associated with the conversion to diabetes in women treated with acarbose ( $p=0.014$; Fig. 2 ).

In the placebo group 73 of 184 subjects $(39.7 \%)$ with the Gly482Gly genotype, 96 of 178 subjects (53.9\%) with the Gly482Ser genotype and the 21 of 52 subjects $(40.4 \%)$ with the Ser482Ser genotype of the $P G C-1 \alpha$ gene developed diabetes $(p=0.017$ over the three genotype groups). In the acarbose group the corresponding numbers were 57 of 150 subjects (38.0\%), 51 of 161 subjects $(31.7 \%)$, and 12 of 45 subjects $(26.7 \%)$. In the placebo group the $482 \mathrm{Ser}$ allele of the $P G C-1 \alpha$ gene, compared to the Gly482Gly genotype, was associated with a higher incidence of diabetes $(p=0.023$; Fig. $1 \mathrm{~b})$. The associa- 
Table 2. The effect of treatment on the conversion to diabetes (\%) according to the genotypes of the $P P A R-\gamma 2$ and the $P G C$ - $1 \alpha$ genes

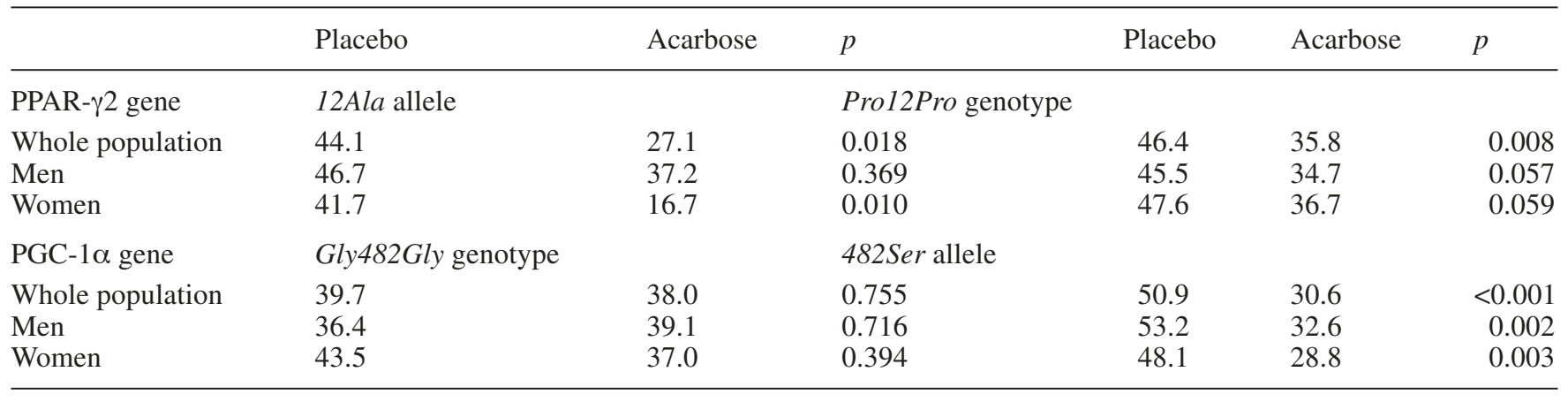

Table 3. The Pro12Ala polymorphism of the PPAR- $\gamma 2$ gene and the Gly $482 S e r$ polymorphism of the $P G C-1 \alpha$ gene as predictors for the development of type 2 diabetes by treatment group (logistic regression analysis)

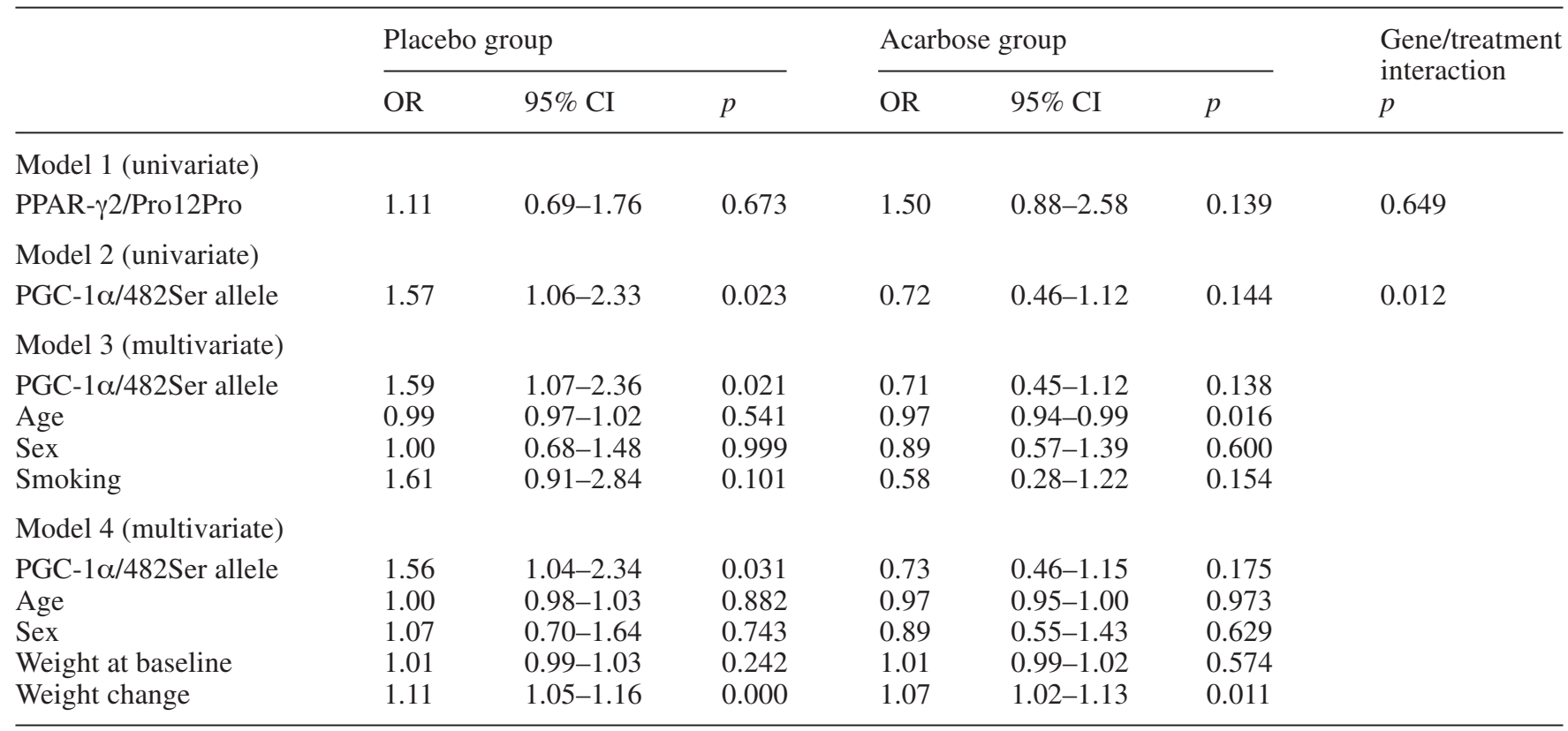

$\mathrm{OR}=$ odds ratio. Smoking was coded as $0=$ never smokers and ex-smokers and $1=$ current smokers at baseline. PPAR- $\gamma 2$ genotypes were coded as $0=$ the 12 Ala allele and $1=$ the

tion in the placebo group was even more marked among men ( $p=0.012)$, as $36.4 \%$ of those (36 of 99) having the Gly482Gly genotype and $53.2 \%$ of those (66 of 124) with the $482 \mathrm{Ser}$ allele converted to diabetes. As shown in Table 2, acarbose was effective in the prevention of diabetes independently of the genotypes of the PPAR- $\gamma 2$ gene in all subjects, but if analysed by sex, women with the 12Ala allele were more responsive to treatment with acarbose than men. In contrast, acarbose treatment prevented the development of diabetes only among carriers of the $482 \mathrm{Ser}$ allele of the $P G C-1 \alpha$ gene in both men and women. There was no difference in weight change with respect to the polymorphisms of the PPAR- $\gamma 2$ or $P G C-1 \alpha$ genes among the different treatment groups or according to sex (data not shown).
Pro12Pro genotype. PGC-1 $\alpha$ genotypes were coded as $0=$ the Gly482Gly genotype and $1=$ the $482 \mathrm{Ser}$ allele

Univariate logistic regression analysis showed that the Pro12Pro genotype of the PPAR- $\gamma 2$ gene was not associated with a higher risk of developing type 2 diabetes in the placebo group or in the acarbose group (Table 3 , Model 1). However, in women the presence of the Pro12Pro genotype was related to a 2.9-fold higher risk (95\% confidence intervals (CI) 1.20 to $6.96 ; p=0.018$ ) of developing diabetes in the acarbose group (Table 4). Adjustment for age and smoking (odds ratio (OR) 2.87, 95\% CI 1.19 to $6.93 ; p=0.019)$, or for age, smoking and the country of origin (OR 2.90, 95\% CI 1.17 to 7.20; $p=0.022$ ) or for age, weight at baseline and weight change (Table 4, Model 4, OR 3.55, 95\% CI 1.38 to 9.13; $p=0.009$ ) did not essentially change the results.

No statistically significant gene-gene interaction was found between the PPAR- $\gamma 2$ and $P G C-1 \alpha$ genes 
Table 4. The Pro12Ala polymorphism of the PPAR- $\gamma 2$ gene as a predictor for the development of type 2 diabetes in the treatment groups by sex (logistic regression analysis)

\begin{tabular}{|c|c|c|c|c|c|c|c|}
\hline & \multicolumn{3}{|c|}{ Placebo group } & \multicolumn{3}{|c|}{ Acarbose group } & \multirow{2}{*}{$\begin{array}{l}\text { Gene/treatment } \\
\text { interaction } \\
p\end{array}$} \\
\hline & OR & $95 \% \mathrm{CI}$ & $p$ & OR & $95 \% \mathrm{CI}$ & $p$ & \\
\hline PPAR- $\gamma 2 /$ Pro12Pro & 0.96 & $0.50-1.86$ & 0.913 & 0.90 & $0.44-1.85$ & 0.767 & 0.662 \\
\hline PPAR- $\gamma 2 /$ Pro12Pro & 1.27 & $0.66-2.46$ & 0.479 & 2.89 & $1.20-6.96$ & 0.018 & 0.289 \\
\hline \multicolumn{8}{|c|}{ Model 3 (multivariate) } \\
\hline $\begin{array}{l}\text { PPAR- } \gamma 2 / \text { Pro } 12 \text { Pro } \\
\text { Age } \\
\text { Smoking }\end{array}$ & $\begin{array}{l}1.23 \\
0.99 \\
1.01\end{array}$ & $\begin{array}{l}0.63-2.40 \\
0.95-1.02 \\
0.44-2.33\end{array}$ & $\begin{array}{l}0.544 \\
0.422 \\
0.975\end{array}$ & $\begin{array}{l}2.87 \\
0.97 \\
0.60\end{array}$ & $\begin{array}{l}1.19-6.93 \\
0.93-1.01 \\
0.20-1.77\end{array}$ & $\begin{array}{l}0.019 \\
0.110 \\
0.352\end{array}$ & \\
\hline
\end{tabular}

$\mathrm{OR}=$ odds ratio. Smoking was coded as $0=$ never smokers and ex-smokers and $1=$ current smokers at baseline. PPAR- $\gamma 2$ genotypes were coded as $0=$ the 12 Ala allele and $1=$ the Pro12Pro genotype

( $p=0.562)$. However, the $482 \mathrm{Ser}$ allele of the $P G C-1 \alpha$ had a significant interaction (interaction term: $P G C$ $1 \alpha / 482$ Ser allele $\times$ treatment group) with the mode of the treatment $(p=0.012)$. In the placebo group subjects with the 482Ser allele had an approximate 1.6-fold increase (95\% CI 1.06 to $2.33, p=0.023$ ) in the risk of developing diabetes (Table 3, Model 2). The results remained essentially unchanged after adjustment for age, sex and smoking (OR 1.59, 95\% CI 1.07 to 2.36; $p=0.021$ ), or for age, sex, smoking and the country of origin (OR 1.53, 95\% CI 1.01 to $2.32 ; p=0.043$ ), or for age, sex, weight at baseline and weight change (odds ratio $1.56,95 \%$ CI 1.04 to $2.34 ; p=0.031$ ).

The 12Ala allele of the PPAR- $\gamma 2$ tended to be related to an increase in conversion to normal glucose tolerance (NGT) in both sexes, but the results were not statistically significant among the different treatment groups (data not shown).

\section{Discussion}

We have shown that the Pro12Pro genotype of the PPAR- $\gamma 2$ gene and the $482 S e r$ allele of the PGC- $1 \alpha$ gene predicts the conversion from IGT to diabetes in the STOP-NIDDM trial. The Prol2Pro genotype of the PPAR- $\gamma 2$ gene was associated with a 2.9 -fold higher risk of developing diabetes compared to the 12Ala allele in women in the acarbose group $(p=0.018)$, whereas the $482 \mathrm{Ser}$ allele of the $P G C-1 \alpha$ gene predicted the conversion to diabetes in the placebo group (OR 1.57, $p=0.023$ ).
There is substantial evidence that $P P A R-\gamma$ contributes to the risk for type 2 diabetes by influencing insulin sensitivity, insulin secretion and susceptibility to obesity [6]. The 12Ala allele of the PPAR- $\gamma 2$ gene, that has been shown to have a decreased transcriptional activity, is also associated with improved insulin sensitivity and lower risk for diabetes [17]. This finding is in agreement with results from heterozygous $P P A R-\gamma$ null mice exhibiting increased insulin sensitivity compared with wild-type mice [46]. The 12Ala allele was associated with a higher reduction in the 2-h serum insulin level, probably indicating an increase in insulin sensitivity. However, it cannot be excluded that a decrease in insulin levels could also be due to impaired insulin secretion, because the 12Ala allele has been associated with reduced insulin secretion capacity in previous studies [20, 47].

$P P A R-\gamma$ plays a key role in adipocyte differentiation $[10,11]$, and can therefore influence body fat mass and obesity. In our study subjects, those with the 12Ala allele had a somewhat higher BMI at baseline, and tended to lose more weight. This finding is in accordance with our results from the Finnish Diabetes Prevention Study [48]. In that study, subjects belonging to the intervention group (lifestyle changes) and who had the Ala12 allele lost significantly more weight (and were protected from type 2 diabetes) than subjects with the Prol2Pro genotype, although in the control group the 12Ala allele did not confer protection against diabetes. In the present study, the effect of the Pro12Pro genotype in increasing the risk for diabetes was independent of baseline weight change and other 
confounding factors in women in the acarbose group, indicating that women possessing the Prol2Pro genotype were less responsive to acarbose treatment. This implies that the effect of acarbose treatment was modified by the Pro12Ala polymorphism.

Several mechanisms could explain why the Gly482Ser polymorphism of the $P G C-1 \alpha$ gene regulates the conversion from IGT to diabetes. $P G C-1 \alpha$ increases and coordinates the expression of different genes that stimulate mitochondrial biogenesis, adaptive thermogenesis, fibre-type switching [32], expression of GLUT-4 in skeletal muscle [33], and regulation of gluconeogenesis in the liver [34]. Thus, a reduction in the activity of $P G C-1 \alpha$, possibly also as a result of the Gly482Ser mutation, might lead to insulin resistance in skeletal muscle. Additionally, a quantitative trait linkage analysis in Pima Indians suggested a link between basal insulin concentrations and chromosome $4 \mathrm{p} 15.1$ [49] in cases where the $P G C$ - $1 \alpha$ gene has been mapped [50]. In the present study the Gly482Ser variant was not related to fasting and 2-h plasma glucose, serum insulin, or their changes, or to BMI and weight change. However, compared to the Gly482Gly genotype, the 482Ser allele was associated with a 1.6-fold higher risk for diabetes in the placebo group but not in the acarbose group. The 482Ser allele had a significant interaction with treatment and acarbose treatment was able to reduce the risk of diabetes particularly among carriers of the $482 \mathrm{Ser}$ allele.

Previous attempts to relate the Gly482Ser polymorphism to type 2 diabetes have shown an 1.34-fold increase in risk among Danish Caucasians [38] and a significant association among Japanese subjects [39]. In contrast, the 482Ser allele did not predict diabetes in French Caucasians or Pima Indians [40, 41]. These studies were carried out in single populations. Because several different populations were used in the STOP-NIDDM trial, our data provides strong evidence that the Gly482Ser polymorphism of the $P G C$ $1 \alpha$ gene contributes to the risk of type 2 diabetes. In agreement with this, the reduced expression of $P G C$ $1 \alpha$ in adipose tissue has been associated with insulin resistance [51]. Moreover, recent studies have reported that down-regulation of the $P G C-1 \alpha$ gene and coordinated changes in other genes involved in oxidative phosphorylation in man are associated with IGT, diabetes mellitus [35] and insulin resistance [37].

The regulation of many important metabolic processes and energy homeostasis by the $P G C-1 \alpha$ gene is achieved through a specific interaction with a variety of transcription factors and nuclear hormone receptors, including PPAR- $\gamma 2$. Moreover, $P G C-1 \alpha$ was first identified as a transcriptional co-activator for $P P A R-\gamma$ [29]. Therefore, it is possible that polymorphisms in both of these genes might interact. In our study no statistically significant interaction which may lead to an increase in the conversion to type 2 diabetes was found between the polymorphisms of the PPAR- $\gamma 2$ and
$P G C$ - $1 \alpha$ genes, this is in accord with the results of a previous study among Danish subjects [38].

In summary, we have demonstrated that the Prol2Pro genotype of the PPAR- $\gamma 2$ gene and the $482 \mathrm{Ser}$ allele of the $P G C-1 \alpha$ gene predict the conversion from IGT to type 2 diabetes. Our study also shows that the interaction between drug treatment (acarbose) and genetic variation may be significant with respect to the conversion from impaired glucose tolerance to type 2 diabetes.

Acknowledgements. The STOP-NIDDM trial and DNA analysis were funded by an unrestricted grant from Bayer AG. We thank Ms. Leena Uschanoff for genotyping.

Duality of interest. J.-L. Chiasson has received research support as well as an honorarium for lectures from Bayer.

\section{References}

1. Kahn CR, Vicent D, Doria A (1996) Genetics of non-insulin-dependent (type-II) diabetes mellitus. Annu Rev Med 47:509-531

2. Medici F, Hawa M, Ianari A, Pyke DA, Leslie RD (1999) Concordance rate for type II diabetes mellitus in monozygotic twins: actuarial analysis. Diabetologia 42:146-150

3. Lehtovirta M, Kaprio J, Forsblom C, Eriksson J, Tuomilehto J, Groop L (2000) Insulin sensitivity and insulin secretion in monozygotic and dizygotic twins. Diabetologia 43:285-293

4. Florez JC, Hirschhorn J, Altshuler D (2003) The inherited basis of diabetes mellitus: implications for the genetic analysis of complex traits. Annu Rev Genomics Hum Genet 4:257-291

5. Rosen ED, Spiegelman BM (2001) PPARgamma: a nuclear regulator of metabolism, differentiation, and cell growth. J Biol Chem 276:37731-37734

6. Gurnell M, Savage DB, Chatterjee VK, O'Rahilly S (2003) The metabolic syndrome: peroxisome proliferator-activated receptor gamma and its therapeutic modulation. J Clin Endocrinol Metab 88:2412-2421

7. Auwerx J (1999) PPARgamma, the ultimate thrifty gene. Diabetologia 42:1033-1049

8. Tontonoz P, Hu E, Graves RA, Budavari AI, Spiegelman BM (1994) mPPAR gamma 2: tissue-specific regulator of an adipocyte enhancer. Genes Dev 8:1224-1234

9. Tontonoz P, Hu E, Spiegelman BM (1994) Stimulation of adipogenesis in fibroblasts by PPAR gamma 2, a lipid-activated transcription factor. Cell 79:1147-1156

10. Rosen ED, Walkey CJ, Puigserver P, Spiegelman BM (2000) Transcriptional regulation of adipogenesis. Genes Dev 14:1293-1307

11. Spiegelman BM (1998) PPAR-gamma: adipogenic regulator and thiazolidinedione receptor. Diabetes 47:507-514

12. Yamauchi T, Kamon J, Waki H et al. (2001) The mechanisms by which both heterozygous peroxisome proliferator-activated receptor gamma (PPARgamma) deficiency and PPARgamma agonist improve insulin resistance. J Biol Chem 276:41245-41254

13. Picard F, Auwerx J (2002) PPAR(gamma) and glucose homeostasis. Annu Rev Nutr 22:167-197

14. Lehmann JM, Moore LB, Smith-Oliver TA, Wilkison WO, Willson TM, Kliewer SA (1995) An antidiabetic thiazolidinedione is a high affinity ligand for peroxisome prolif- 
erator-activated receptor gamma (PPAR gamma). J Biol Chem 270:12953-12956

15. Tenenbaum A, Fisman EZ, Motro M (2003) Metabolic syndrome and type 2 diabetes mellitus: focus on peroxisome proliferator activated receptors (PPAR). Cardiovasc Diabetol 2:14

16. Yen CJ, Beamer BA, Negri C et al. (1997) Molecular scanning of the human peroxisome proliferator activated receptor gamma (hPPAR gamma) gene in diabetic Caucasians: identification of a Pro12Ala PPAR gamma 2 missense mutation. Biochem Biophys Res Commun 241:270-274

17. Deeb SS, Fajas L, Nemoto M et al. (1998) A Pro12Ala substitution in PPARgamma2 associated with decreased receptor activity, lower body mass index and improved insulin sensitivity. Nature Genet 20:284-287

18. Hara K, Okada T, Tobe K et al. (2000) The Pro12Ala polymorphism in PPAR gamma2 may confer resistance to type 2 diabetes. Biochem Biophys Res Commun 271:212-216

19. Altshuler D, Hirschhorn JN, Klannemark M et al. (2000) The common PPARgamma Pro12Ala polymorphism is associated with decreased risk of type 2 diabetes. Nature Genet 26:76-80

20. Mori H, Ikegami H, Kawaguchi Y et al. (2001) The Pro12 $\rightarrow$ Ala substitution in PPAR-gamma is associated with resistance to development of diabetes in the general population: possible involvement in impairment of insulin secretion in individuals with type 2 diabetes. Diabetes 50:891-894

21. Douglas JA, Erdos MR, Watanabe RM et al. (2001) The peroxisome proliferator-activated receptor-gamma2 Pro12A1a variant: association with type 2 diabetes and trait differences. Diabetes 50:886-890

22. Memisoglu A, Hu FB, Hankinson SE et al. (2003) Prospective study of the association between the proline to alanine codon 12 polymorphism in the PPARgamma gene and type 2 diabetes. Diabetes Care 26:2915-2917

23. Ringel J, Engeli S, Distler A, Sharma AM (1999) Pro12Ala missense mutation of the peroxisome proliferator activated receptor gamma and diabetes mellitus. Biochem Biophys Res Commun 254:450-453

24. Mancini FP, Vaccaro O, Sabatino L et al. (1999) Pro12Ala substitution in the peroxisome proliferator-activated receptor-gamma 2 is not associated with type 2 diabetes. Diabetes 48:1466-1468

25. Oh EY, Min KM, Chung JH et al. (2000) Significance of Pro12Ala mutation in peroxisome proliferator-activated receptor-gamma2 in Korean diabetic and obese subjects. J Clin Endocrinol Metab 85:1801-1804

26. Meirhaeghe A, Fajas L, Helbecque N et al. (2000) Impact of the Peroxisome Proliferator Activated Receptor gamma2 Pro12Ala polymorphism on adiposity, lipids and non-insulin-dependent diabetes mellitus. Int J Obes Relat Metab Disord 24:195-199

27. Clement K, Hercberg S, Passinge B et al. (2000) The Pro115Gln and Pro12Ala PPAR gamma gene mutations in obesity and type 2 diabetes. Int J Obes Relat Metab Disord 24:391-393

28. Lei HH, Chen MH, Yang WS et al. (2000) Peroxisome proliferator-activated receptor gamma 2 Pro12Ala gene variant is strongly associated with larger body mass in the Taiwanese. Metabolism 49:1267-1270

29. Puigserver P, Wu Z, Park CW, Graves R, Wright M, Spiegelman BM (1998) A cold-inducible coactivator of nuclear receptors linked to adaptive thermogenesis. Cell 92:829-839

30. Wu Z, Puigserver P, Andersson U et al. (1999) Mechanisms controlling mitochondrial biogenesis and respiration through the thermogenic coactivator PGC-1. Cell 98: 115-124

31. Puigserver P, Spiegelman BM (2003) Peroxisome proliferator-activated receptor-gamma coactivator 1 alpha (PGC-1 alpha): transcriptional coactivator and metabolic regulator. Endocr Rev 24:78-90

32. Lin J, Wu H, Tarr PT et al. (2002) Transcriptional co-activator PGC-1 alpha drives the formation of slow-twitch muscle fibres. Nature 418:797-801

33. Michael LF, Wu Z, Cheatham RB et al. (2001) Restoration of insulin-sensitive glucose transporter (GLUT4) gene expression in muscle cells by the transcriptional coactivator PGC-1. Proc Natl Acad Sci USA 98:3820-3825

34. Yoon JC, Puigserver P, Chen G et al. (2001) Control of hepatic gluconeogenesis through the transcriptional coactivator PGC-1. Nature 413:131-138

35. Mootha VK, Lindgren CM, Eriksson KF et al. (2003) PGC-1alpha-responsive genes involved in oxidative phosphorylation are coordinately downregulated in human diabetes. Nature Genet 34:267-273

36. Attie AD, Kendziorski CM (2003) PGC-1alpha at the crossroads of type 2 diabetes. Nature Genet 34:244-245

37. Patti ME, Butte AJ, Crunkhorn S et al. (2003) Coordinated reduction of genes of oxidative metabolism in humans with insulin resistance and diabetes: potential role of PGC1 and NRF1. Proc Natl Acad Sci USA 100:8466-8471

38. Ek J, Andersen G, Urhammer SA, Gaede PH et al. (2001) Mutation analysis of peroxisome proliferator-activated receptor-gamma coactivator-1 (PGC-1) and relationships of identified amino acid polymorphisms to Type II diabetes mellitus. Diabetologia 44:2220-2226

39. Hara K, Tobe K, Okada T et al. (2002) A genetic varia-tion in the PGC-1 gene could confer insulin resistance and susceptibility to Type II diabetes. Diabetologia 45:740-743

40. Lacquemant C, Chikri M, Boutin P, Samson C, Froguel P (2002) No association between the G482S polymorphism of the proliferator-activated receptor- gamma coactivator-1 (PGC-1) gene and Type II diabetes in French Caucasians. Diabetologia 45:602-603; author reply 604

41. Muller YL, Bogardus C, Pedersen O, Baier L (2003) A Gly482Ser missense mutation in the peroxisome proliferator-activated receptor gamma coactivator- 1 is associated with altered lipid oxidation and early insulin secretion in Pima Indians. Diabetes 52:895-898

42. Chiasson JL, Gomis R, Hanefeld M, Josse RG, Karasik A, Laakso M (1998) The STOP-NIDDM Trial: an international study on the efficacy of an alpha-glucosidase inhibitor to prevent type 2 diabetes in a population with impaired glucose tolerance: rationale, design, and preliminary screening data. Study to Prevent Non-Insulin-Dependent Diabetes Mellitus. Diabetes Care 21:1720-1725

43. World Health Organization (1985) Diabetes mellitus. WHO, Geneva, pp 10-11

44. Chiasson JL, Josse RG, Gomis R, Hanefeld M, Karasik A, Laakso M (2002) Acarbose for prevention of type 2 diabetes mellitus: the STOP-NIDDM randomised trial. Lancet 359:2072-2077

45. Albareda M, Rodriguez-Espinosa J, Murugo M, Leiva A de, Corcoy R (2000) Assessment of insulin sensitivity and beta-cell function from measurements in the fasting state and during an oral glucose tolerance test. Diabetologia 43:1507-1511

46. Kubota N, Terauchi Y, Miki H et al. (1999) PPAR gamma mediates high-fat diet-induced adipocyte hypertrophy and insulin resistance. Mol Cell 4:597-609

47. Stefan N, Fritsche A, Haring H, Stumvoll M (2001) Effect of experimental elevation of free fatty acids on insulin se- 
cretion and insulin sensitivity in healthy carriers of the Pro12Ala polymorphism of the peroxisome proliferatoractivated receptor-gamma2 gene. Diabetes 50:1143-1148

48. Lindi VI, Uusitupa MI, Lindström J, et al. for the Finnish Diabetes Prevention Study Group (2002) Association of the Pro12Ala polymorphism in the PPAR-gamma2 gene with 3-year incidence of type 2 diabetes and body weight change in the Finnish Diabetes Prevention Study. Diabetes 51:2581-2586

49. Pratley RE, Thompson DB, Prochazka M et al. (1998) An autosomal genomic scan for loci linked to prediabetic phenotypes in Pima Indians. J Clin Invest 101:1757-1764
50. Esterbauer H, Oberkofler H, Krempler F, Patsch W (1999) Human peroxisome proliferator activated receptor gamma coactivator 1 (PPARGC1) gene: cDNA sequence, genomic organization, chromosomal localization, and tissue expression. Genomics 62:98-102

51. Hammarstedt A, Jansson PA, Wesslau C, Yang X, Smith U (2003) Reduced expression of PGC-1 and insulin-signaling molecules in adipose tissue is associated with insulin resistance. Biochem Biophys Res Commun 301:578-582 